УДК 37.13:373.3(091)[(410)+(430)]

Л. П. Поліщук,

кандидат педагогічних наук

(Житомирський державний університет імені Івана Франка)

Ludmialp28@gmail.com

ORCID: 0000-0002-9468-5412

\title{
ОСНОВНІ НАПРЯМКИ ПРОФЕСІЙНОЇ ПІДГОТОВКИ МАЙБУТНІХ ПЕРЕКЛАДАЧІВ В УМОВАХ ЄВРОІНТЕГРАЦІї
}

У статті розглядаються радикальні зміни у системі професійної підготовки майбутніх перекладачів, які зумовлені такими зовнішніми чинниками, як інтеграційні процеси у галузі перекладацької освіти, щзо спрямовані на створення єдиного європейського простору освіти. Розкрито проблематику вітчизняних педагогічних досліджень у сфері професійної підготовки перекладачів у вищих навчальних закладах України. Запропоновано власне бачення пріоритетних напрямів удосконалення вітчизняної системи перекладацької освіти. Визначено перспективи подальших розвідок з иієї теми.

Ключові слова: професійна підготовка, майбутні перекладачі, інтеграційні прочеси, єдиний європейський простір, комунікативні здібності.

Вступ. Інтеграції вітчизняної системи освіти в європейський простір, пов'язана $з$ переосмисленням вітчизняного досвіду і пошуком ефективних шляхів іiі реорганізації, що відбулося внаслідок економічних, політичних та соціальних змін у кінці XX - на початку XXI століття.

Такі явища, як Болонський процес, інтеграція та модернізація виступають основним чинником сучасних змін в освіті, та являються головною складовою реформування системи професійної підготовки майбутніх перекладачів. Ставши повноправним учасником Болонського процесу, Україна скоординувала 3 ним пріоритети розвитку вищої освіти і здійснює реорганізацію освітньої діяльності в контексті європейських орієнтирів. Національна доктрина розвитку освіти України у ХХІ столітті (2002 р.) включає модернізацію методів та змісту, форм навчання, запровадження та розроблення державних стандартів педагогічної освіти. Більш детальна інформація щодо реорганізацій зазначена в Програмі дій щодо реалізації положень Болонської декларації у системі вищої освіти і науки Україні (2004 р.) та Законі України "Про вищу освіту" (2006 р.), де передбачається грунтовна практична, фахова та психологічна підготовка студентів перекладачів.

Метою статті $\epsilon$ окреслення головних аспектів удосконалення професійної підготовки майбутніх перекладачів, що розглядає як інноваційні, так і традиційні напрямки у професійній підготовці. Інноваційні та модернізовані напрямки у розвитку суспільства можливі при повній реорганізації покоління людей, які будуть мислити і діяти інноваційно. Тому значна увага сфокусована на загальний розвиток особистості, іiі комунікативних здібностей, готовності самостійно приймати рішення, критичності мислення та розвитку інформаційних і соціальних навичок.

Актуальність дослідження зумовлена необхідністю реорганізації та модернізації системи професійної підготовки майбутніх викладачів, а також існуючими суперечностями між: потребою суспільства у висококваліфікованих перекладачах, здатних функціонувати на сучасному ринку праці і недостатнім рівнем їх підготовки; необхідністю введення єдиної системи стандартів професійної підготовки перекладача та шляхами їх реалізації; потребою модернізації змісту професійної підготовки майбутніх перекладачів та шляхами їх реалізації.

Аналіз останніх досліджень і публікацій. Українськими вченими накопичено значний досвід використання здобутків зарубіжної теорії професійної освіти. Інтерес науковців сфокусовано на: спеціалізації перекладацької освіти, кваліфікаційні напрями підготовки перекладачів (Н. Гавриленко, В. Карабан, А. Козак, С. Коломієць, Р. Крісс, Е. Пім, Л. Черноватий); організації професійної підготовки перекладачів у вищих навчальних закладах України та США (Є. Бесєдіна, К. Клауді, О. Ковязіна, А. Козак, В. Радчук, Б. Рубрехт, Р. Тінслей); педагогічні умови формування і складові професійної компетенції перекладача (Л. Бархударов, В. Ільїн, А. Козак, Л. Латишев, Г. Мірам, Н. Миронова, Л. Мітіна, С. Ніколаєва, Ю. Пассов, 3. Підручна, Н. Соболь, Л. Тархова, А. Федоров, І. Халєєва, М. Цвіллінг, Ю. Хольц-Мянттярі);

Виклад основного матеріалу. Найголовнішою проблемою підготовки кваліфікованих перекладачів, спроможних ефективно задовольнити конкретні сегменти ринку праці, є потреба поєднання ними знань іноземної мови зі знаннями специфіки галузі їхньої професійної діяльності. Для того, щоб кожний перекладач міг забезпечити високоякісне виконання тих вимог, які висуває практика міжкультурної комунікації, в процесі професійної підготовки необхідно ретельно визначити та врахувати професійні навички та уміння, одночасно звертаючи увагу на творчий характер перекладацької діяльності.

Рівень знань майбутніх перекладачів повною мірою залежить від їхньої професійної підготовки. Професія перекладача вимагає глибоких знань (загальнокультурних в галузі історії, літератури і 
країнознавства, екстралінгвістичних, лінгвістичних, а також знання, які необхідні для перекладу в різних галузях - техніці, юриспруденції, політиці, освіті, медицині та ін.). Також, професійна підготовка майбутніх перекладачів - це процес формування комунікативної компетентності, що передбачає володіння іноземної мови на високому рівні, близькому до рівня носія мови.

Головна мета викладача вищого навчального закладу - ознайомити студентів 3 труднощами перекладу. Студенти повинні знати, що переклад повинен передати те, що написано, а також у ньому має бути точність відповідно до оригіналу.

Головним шляхом опанування професії перекладача $\epsilon$ перехід від знань - до умінь, та від умінь - до навичок. 3 точки зору методики необхідно, щоб уміння, сформовані у майбутніх перекладачів на базі теоретичних знань, створювали такий міст, який дозволяє уникнути розриву між теоретичним так практичним курсом, що є типовим у процесі підготовки студентів у вітчизняних навчальних закладах.

Спеціалізація перекладацької освіти зумовлена специфікою перекладу тих чи інших текстів. У ефективності теоретичного підгрунтя у процесі підготовки перекладачів визначено три підходи у підборі навчального матеріалу для практичного закріплення теорії перекладу: індуктивний, дедуктивний та функціональний. Перший із них передбачає переклад обраних викладачем 10-15 текстів протягом семестру $з$ подальшою перевіркою, обговоренням результатів роботи та узагальненням рекомендацій щодо вирішення певних перекладацьких проблем. Дедуктивний підхід базується на тематичному розвитку техніки перекладу, коли викладач формулює тему для опрацювання (наприклад, переклад власних назв, одиниць вимірювання тощо), а вже потім обирає до неї практичні завдання. Останній із названих підходів полягає у формуванні окремих навичок перекладацької діяльності за допомогою виконання відповідних практичних завдань [1].

Необхідністю при ефективному навчанні становить обсяг навчального матеріалу, який повинен бути наближеним до реальних завдань професійного перекладача; також, навчальний матеріал має оновлюватись кожен рік. Головним завданням у процесі формування перекладацької компетенції $\epsilon$ оволодіння навичками якісного та швидкого оформлення перекладацьких завдань, що включають навички сучасних інформаційних технологій. Необхідно зазначити, що важливим аспектом навчальних програм філологічних вузів має бути можливість навчання або перекладацької практики у країні, мова якої вивчається, оскільки це дає можливість удосконалення комунікативних навичок майбутнього перекладача.

Отже, головним аспектом підготовки кваліфікованих перекладачів є забезпечення їх комплексом знань, умінь та навичок професійної компетенції фахівця та необхідність ознайомлення із специфікою перекладацької діяльності у тій чи іншій галузі.

Американським науковцем Б. Рубрехтом були розроблено 10 концепцій, які повною мірою відображають характер навчальної діяльності та професії перекладача: знання іноземної мови $\epsilon$ необхідним, але недостатнім для перекладацької діяльності; переклад є частиною, а не результатом процесу вивчення мови; перекладач має виховати у собі силу волі; кінцева мета студентів-перекладачів досягти розуміння людьми їх перекладу; не всі практичні завдання є цікавими для студентів; студенти не стають професійними перекладачами у стінах навчального закладу; усі запропоновані викладачем вправи мають відповідати поставленій ним меті; перекладацька майстерність вимагає більшого, ніж розуміння значення окремих слів; завершений переклад ніколи не буває завершеним остаточно; переклад, передусім, потребує дисципліни [2].

Необхідно зазначити, що професійні перекладачі мають бути добре ознайомлені зі структурою та стилістичними особливостями вихідної та цільової мов; важливим компонентом освітньо-професійної програми має стати дослідження літератури країни, мова якої вивчається. Так, наприклад, порівнюючи особливості перекладу художньої і технічної літератури, основне завдання перекладача художнього тексту - висвітлення літературних образів, тоді як технічний перекладач має передавати факти. Саме тому перекладач технічної літератури повинен знати предмет перекладу і володіти властивим цьому жанру стилем [3].

Особливими частинами перекладацької компетенції можна також вважати знання, уміння та навички, які необхідні в споріднених видах перекладу (усний або письмовий) незалежно від жанру (науковотехнічний, діловий, газетний або публіцистичний). Перекладацька діяльність може бути як у письмовій, так і усній формі. Кожна форма має особливість, яка вимагає від перекладача необхідних професійних вмінь та навичок.

Обидві форми перекладу - письмовий і усний є однаково важкими. Відомі факти, коли студенти, які мають здібності у письмовому перекладі, мають труднощі в усному. Ці протилежні види роботи потребують різних фахових здібностей майбутніх викладачів. У першому випадку у студента є час на розв'язання перекладацьких проблем, а в іншому випадку - його немає. Вхідні тексти письмового перекладу завжди складніші. Усний переклад знаходить застосування в русі мовних жанрів - дискусії, публічні виступи, інтерв'ю. Тексти підвищеної складності (науково-технічні, художні, публіцистичні), в більшості випадків, перекладаються письмово. 
До специфічних умінь перекладача, що виконує письмовий переклад, відносяться уміння не тільки користуватися словниками, а також аналізувати вхідний текст та редагувати свій переклад. Для усного перекладу перекладачеві необхідно володіти знаннями найбільш частотних, застосовуваних перекладацьких відповідностей та автоматичні навички їх використання. У перекладача обмежений час, щоб підібрати необхідний еквівалент-термін. Довгі паузи та вагання заважають адекватному сприйманню перекладеного тексту, порушують комунікацію між партнерами. Якщо перекладач не знає правил коректного застосування слів-синонімів, це значно знецінює знання слів, особливо при перекладі 3 рідної мови на іноземну. Отже, необхідно зазначити, що міцність запам'ятання мовних одиниць базується на постійному, багаторазовому повторенні.

До спеціальної складової частини перекладацької компетенції можна додати знання предмета висловлювання та володіння термінологічними одиницями, які мають фахову спрямованість тексту. Перекладачеві доцільно знати термінологічні одиниці у двох мовних поняттях. Якщо перекладач знає назви всіх складових частин літака, але не знає принципу дії, то роль мовного посередника не буде тривалою. Сучасний перекладач повинен постійно вдосконалювати знання у своїй галузі та набувати практичних навичок з оволодіння двомовними термінологічними одиницями.

Мовна компетенція перекладача включає всі аспекти володіння мовою, характерні для будь-якого носія мови, але, крім того, має специфічні особливості. Успішний обмін мовними творами в процесі комунікації передбачає наявність у комунікантів текстотвірні компетенції, вміння створювати тексти різного типу згідно з прийнятими у даному мовному колективі правилами і стереотипами. Професійна компетенція перекладача включає особистісні характеристики, без яких він не зможе успішно виконувати свої професійні функції.

Для перекладача ефективний шлях пізнання відповідної предметної області з одночасним засвоєнням термінології - відразу або послідовно на двох мовах. Таким є перший комплекс завдань під час підготовки перекладача. Другий комплекс завдань - це практичне тренування в перекладі 3 використанням знань і термінології з відповідної предметної області.

Завдання першого комплексу вирішуються за допомогою лексико-перекладацького комплексу занять, введення в предмет на заняттях, завдань на самостійне вивчення предмета висловлювання. Завдання другого комплексу вирішуються в опануванні наступними уміннями: вміння передавати в перекладі поняття не за допомогою термінів, а за допомогою описового перекладу; вміння сходу утворювати якщо не терміни, то такі найменування для понять, суть яких була б зрозуміла.

Зміст курсу перекладу повинен вміщувати як повідомлення необхідних професійних знань, так i розвиток перекладацьких умінь і навичок. При цьому вміння та навички перекладу і складають кінцеву мету курсу перекладу, тому що вони забезпечують практичну професійну діяльність перекладача. Уміння та навички перекладу формуються на основі використання спеціально підібраних навчальних матеріалів. До числа таких матеріалів відносяться перекладацькі вправи і навчальні тексти.

Підводячи підсумок, необхідно зазначити, що специфіка усного та письмового перекладу зумовлює наявність у перекладача фонових знань, умінь і навичок, необхідних для успішної професійної діяльності у певній сфері. Багато науковців наголосили про важливість такої складової професійної компетентності вузькопрофільного перекладача, як предметна та тематична компетенція, а також необхідність оволодіння знаннями у сфері майбутньої професійної діяльності та декларативних знань - про ринок праці, вимоги клієнтів, норми поведінки та стосунки між перекладачем і клієнтом, джерела інформації, інструменти перекладу тощо, а також процесуальних знань - про особливості професійного перекладу [4].

Висновки та перспективи подальших досліджень. Аналіз педагогічних досліджень вітчизняних науковців показав, що проблеми професійної підготовки перекладачів залишаються актуальними і на сучасному етапі розвитку освіти України. Необхідно зазначити, що концепція перекладацької освіти базується на компетентісному підході у навчанні майбутніх перекладачів. Професійна компетенція перекладача повинна спрямовуватися на забезпечення письмової та усної комунікації у різних сферах суспільної діяльності; використання сучасних методів знаходження та оброблення інформації, використання глобальних інформаційних мереж, автоматизованих пошукових систем, електронних баз даних, глосаріїв та довідників; проведення наукових досліджень у сфері професійної діяльності.

\section{СПИСОК ВИКОРИСТАНИХ ДЖЕРЕЛ ТА ЛІТЕРАТУРИ}

1. Таланова Ж. П. Педагогічні умови формування професійного світогляду майбутнього перекладача : автореф. дис. на здобуття наук. ступеня канд. пед. наук : спец. 13.00.04 "Теорія і методика професійної освіти" / Ж. П. Таланова. - Кіровоград. - 2007. - 20 с.

2. Rubrecht Brian G. Knowing Before Learning : Ten Concepts Students Should Understand Prior to Enrolling in a University Translation or Interpretation Class [Електронний ресурс] / Brian G. Rubrecht // Translation Journal 2005. - Vol. 9. - No. 2. - Режим доступу : http://translationjournal.net/journal//32edu.htm.

3. Мирам Г. Э. Профессия : переводчик / Г. Э. Мирам. - К. : Ника-Центр, 1999. - 144 с. 
4. Gile D. Basic Concepts and Models for Interpreter and Translator Training / D. Gile. - John Benjamins Publishing Company, 2009. -283 p.

\section{REFERENCES (TRANSLATED \& TRANSLITERATED)}

1. Talanova Z. P. Pedagogichni umovy phormuvania profesiynogo svitoglyadu maibutnogo perekladacha [Pedagogical Conditions of the Professional Outlook of Future Interpreter] : aftoref. dis. na zdobuttia nauk. stupenia kand. ped. nauk : spets. 13.00.04 "Teoria i metodika profesiinoi osvity" / Z. P. Talanova. - Kirovograd. - 2007. - $20 \mathrm{~s}$.

2. Rubrecht Brian G. Knowing Before Learning : Ten Concepts Students Should Understand Prior to Enrolling in a University Translation or Interpretation Class / Brian G. Rubrecht // Translation Journal - 2005. - Vol. 9. - No. 2. Rezhym dostupu : http://translationjournal.net/journal//32edu.htm.

3. Miram G. E. Profesiia : perevodchik [The Profession of Transater] / G. E. Miram. - K. : Nika - Tsenter, 1999. $144 \mathrm{~s}$.

4. Gile D. Basic Concepts and Models for Interpreter and Translator Training / D. Gile. - John Benjamins Publishing Company, 2009. -283 p.

\section{Полищук Л. П. Основные направления подготовки будущих переводчиков в условиях евроинтеграции.}

В статье раскрывается проблема профессиональной подготовки будущих переводчиков в высиих учебных заведениях Украины. Рассмотрены основные концепџии специализации, которые в полной мере отображают характер учебной деятельности и профессии будущих переводчиков в высших учебных

заведениях, определены задания, направлены на формирования профессиональной компетенции

студентов. Предложено собственное видение приоритетных направлений усовершенствования системы образования будущих переводчиков. Определены перспективы дальнейших исследований по этой теме.

Ключевые слова: профессиональная подготовка, будущие переводчики, основные концепции специиализации, интеграциионные процессы, европейское пространство, коммуникативные способности.

\section{Polischuk L. P. The Main Direction of Future Translators Training in Conditions of European Integration.}

The article highlights the problems of Ukrainian pedagogical researches in the sphere of professional translator training in the higher educational establishments of Ukraine. The new aspects of specialization during translator training were suggested. The article discovers the radical changes in the system of professional translator training in Ukraine which dependent on such outside factors as integration in the sphere of education and direct to the formation of integral European area and the introduction of the integral demands to the professional translator training. New perspectives of further researches were defined. The vision of priority directions for improving the education system of future translators were suggested. The most typical way of mastering the profession was determined. Three approaches were considered in the selection of educational material for the practical fixing of the theory of translation. The acquaintance with the 10 concepts of American scientist

$B$. Rubrecht, which fully reflect the nature of the educational activities and the profession of translator. Two sets of tasks are defined for an effective way of knowing the corresponding subject area with the simultaneous learning of terminology. It was noted that the concept of translational education is based on a competent approach to the training of future professionals.

Key words: future translator training, pedagogical researches, professional translator training, higher educational establishments of Ukraine, process of integration, European area, communicative skills. 